\title{
Relationship between organizational commitment and turnover intentions of academics
}

\author{
Özgün Parasız ${ }^{1}$ \\ Mustafa Koç \\ Ebru Ilgar ${ }^{3}$ \\ Mustafa Yaşar Şahin ${ }^{4}$
}

\begin{abstract}
In this study, it is aimed to determine the level of organizational commitment of academics working in Department of Physical Education and Sports and identify its relationship with the intention to cease of employment. Organizational Commitment Scale, consisting of 18 questions, developed by Meyer and Allen (1997), adapted to Turkish by Varol (2010) and Scale of Turnover Intentions developed by Rosin and Korabik (1995), adapted to Turkish by Tanriöver (2005) have been carried out on 143 academics chosen via random sampling method in this relational screening model research. The result of the research has shown that sub-dimension of Emotional Commitment of academics' constitutes the core element and intention to leave is low. Variables of gender and marital status are found to have no effect on the relationship between organizational commitment and intention to leave. On the other hand, academics with an administrative role display a meaningful difference. In regards to the correlation results within the scales, there is a negative and mid-level relationship between emotional commitment level and intention to leave, and a negative and low-level relationship between the level of normative commitment and case of employment.
\end{abstract}

Keywords: Organizational Commitment, Turnover Intentions, Academics, Organization

\section{Introduction}

Developments like alteration, globalization, advanced information technologies and changing dimension of competition concept require that the factors of management and human are taken up at different rates (Özdemir and Yayl1, 2014). In this respect, human factor has recently become a value rather than an inter-organizational human resource. In management science, the concept of organizational commitment to which importance is attributed to an organizational behavior type has become and becomes a source for a lot of researchers as one of the most important topics of organizational behavior and organizational psychology (Swailes, 2002; Ermiş, 2014; Tolukan, Bayrak and Karacan Dogan, 2017).

Organizational commitment means the strength of relationships that employees feel for the organization where they work. It is believed that the feeling of organizational commitment affects organizational performance positively. In addition to this, like universities it is necessary for the

\footnotetext{
${ }^{1}$ MSc, Gazi University Faculty of Sport Sciences, oparasiz@gazi.edu.tr

2 Asst. Prof., Adiyaman University Faculty of Sport Sciences, mustafakoc.7483@gmail.com

${ }^{3}$ Asst. Prof, Bozok University, Faculty of Sport Sciences, ebruarac@hotmail.com

${ }^{4}$ Assoc. Prof., Gazi University Faculty of Sports Sciences, mysahin@gmail.com
} 
Parasız, Ö., Koç, M., Ilgar, E., \& Şahin, M. Y., (2017). Relationship between organizational commitment and turnover intentions of academics. Journal of Human Sciences, 14(4), 4065-4076. doi:10.14687/jhs.v14i4.5076

foundations which aim for producing qualified output to incorporate qualified labor force to their structure, keep them in the organization, increase "positive feelings" that an individual feels for his/her job and take maximum performance from them (Ermiş, 2014).

In the researches of management science, it is generally approved that the components of organizational commitment have effects on a lot of organizational behavior and attitude both separately and also interactively. Foremost among the variables related to organizational commitment is the turnover intention (Allen and Meyer, 1991).

From this point of view; in this study, organizational commitment levels and turnover intentions of academics working in the schools of physical education and sports at universities and the relationship between them will be examined.

\section{Organizational Commitment}

Organizational commitment is defined as an individual's belief of aims and values of an organization, willingness to make an endeavor for reaching the purposes of the organization and desire for staying as a member of the organization. In first studies related to organizational commitment, it is defined as adopting aims and values of the organization, making an effort as an organization member and feeling as a member of a strong family (Swailes, 2002).

Vanderberg and Scarpella (1994) define organizational commitment as "believing aims and value judgments of the corporation, accepting them (bureaucratic structure of the corporation, loyalty to corporation, norms and regulations) and volunteering for struggling on behalf of corporation". As one of the leading researchers with respect to organizational commitment, Porter and Steers (1974) define the relation in the organization as individual's expressing himself with organization and getting involved in a force or an organization that can be integrated with the presence of the individual.

\section{Organizational commitment dimensions}

Organizational commitment has been examined in different dimensions by researchers. When the studies related to organizational commitment in the corresponding literature have been examined, it is understood that "Three-Component Model of Organizational Commitment" based on the studies of Allen and Meyer (1990) is generally accepted (Bağc1 and Bursal1, 2011). These components are Emotional Commitment, Continuance Commitment and Normative Commitment.

Emotional commitment includes employee's identifying himself with the organization and attending to the organization. The employees whose emotional commitments are strong feel desire to stay in the organization in accordance with their requests emotionally. The employee begins to see himself as a part of the organization. Employee's acceptance of the aims and values of the organization is effective on the occurrence of the emotional commitment (Somuncu, 2008).

Continuance commitment is the one that occurs with the thought of losing gains like money, abilities related to the job, seniority, social security, pension right that employees achieve or will achieve in exchange for the labor and time that they spend within the period of continuing to the organization as a result of leaving the organization (Allen and Meyer, 1990).

Normative (moral) commitment is an indicator of employees' feelings of obligation related to staying in the organization. It is an obligation that the employee adheres to the organization in return for all the expenses done for their education and future as from the employment process of the employee (Özdemir and Yayli, 2014).

\section{Turnover intention}

Turnover intention is one of the subjects among organizations. Especially the turnover intention of qualified personals working in the jobs that require high and expensive education places a burden like training cost, losing talent and improvement cost to that workplace. For this reason, turnover intention is one of the most important subjects among organizations (Solmaz, 
Parasız, Ö., Koç, M., Ilgar, E., \& Şahin, M. Y., (2017). Relationship between organizational commitment and turnover intentions of academics. Journal of Human Sciences, 14(4), 4065-4076. doi:10.14687/jhs.v14i4.5076

2010). Turnover intention is the conscious and deliberate decision or intention of the employees about leaving the organization (Barlett, 1999).

\section{Methodology}

This part includes information about the research model, study group, data collection tools and analysis of the data.

\section{Research model}

In this research, it is aimed to examine the relationships between organizational commitment levels and turnover intentions of academics working in the schools of physical education and sports of state universities. In this regard, this research has been conducted with a correlational research model that is involved in quantitative research methods. Within the scope of this research, it is examined whether academics' organizational commitment levels and their turnover intentions show significant differences according to some demographic features (gender, marital status, term of employment, availability of administrative role). In the difference tests calculated in order to make these comparisons, organizational commitment and turnover intention are determined as a dependent variable; demographic features are determined as an independent variable.

\section{Participants}

This study has been carried out with 143 academics chosen via random sampling method in this relational screening model research. Who work as a lecturer or a teaching assistant in the schools of physical education and sports at state universities in Turkey.

Demographic features of the academics whose opinions are received within the scope of this study are shown in Table-1.

\begin{tabular}{llrrr}
\hline Variables & Categories & $\mathbf{n}$ & $\mathbf{\%}$ \\
\hline Gender & Female & 33 & 23,1 \\
\cline { 2 - 5 } & Male & 110 & 76,9 \\
\hline Marital Status & Married & 106 & 74,1 \\
\cline { 2 - 5 } & Single & 37 & 25,9 \\
\hline \multirow{2}{*}{ Term of employment } & $1-2$ years & 23 & 16,1 \\
\cline { 2 - 5 } & 3-8 years & 37 & 25,9 \\
\cline { 2 - 5 } & $9-14$ years & 37 & 25,9 \\
\cline { 2 - 5 } & 15 years and above & 46 & 32,2 \\
\hline $\begin{array}{l}\text { Availability } \\
\text { role }\end{array}$ & an administrative & Yes & 97 & 67,8 \\
\cline { 2 - 5 } & No & &
\end{tabular}

\section{Data collection tools}

In this study, "Individual Information Form" is used to determine demographic features of the academics working in the schools of physical education and sports at state universities, "Organizational Commitment Scale" is used to determine their organizational commitment levels and "Turnover Intention Scale" is used to determine their turnover intentions.

\section{Individual information form}

An individual information form including information about academics'gender, marital status, term of employment and availability of an administrative role has been prepared. In this information form, categories have been constituted for each variable and participants are asked for 
marking appropriate categories. The individual information form has been placed prior to the scales.

\section{Organizational commitment scale}

The "Organizational Commitment Scale" developed by Meyer and Allen (1996) has been used by a lot of researchers abroad (Dunham, Grube and Casteneda, 1994; Hackett, Bycio and Hausdorf, 1994). In this scale adapted to Turkish by Varol (2010), there are 18 items collected in three dimensions totally. The items have been graded in five point likert type.

That the items take part in three dimensions has been determined both in the original scale and also during the adaptation process. These dimensions are emotional commitment, continuance commitment and normative commitment. There are six items in each sub-dimension. While one of the items (I13) is composed of negative statements, other items have positive quality. The negative item is implicated in the analysis by reversing. In each sub-dimension, high scores show that individuals have high commitment levels and low scores indicate that individuals have low commitment levels.

Confirmatory factor analysis has been evaluated in the validity and reliability study of Varol (2010), and it has been identified that conformity indexes which are calculated in order to determine the model-data fit of 18 -item and three-factor model are $\mathrm{X}^{2} / \mathrm{df}=2,3$; CFI $=0,90$; TLI $=0,89$ and RMSEA $=0,08$. It is determined that Cronbach's alpha coefficients calculated to identify the reliability of the answers given to the items of scale are also acceptable in other studies. For example, Güner (2007) states that internal consistency coefficient is 0,62 for emotional commitment, 0,71 for continuance commitment and 0,72 for normative commitment.

Within the context of this research, the opinions of the academics working in the schools of physical education and sports of state universities have been received. Confirmatory factor analysis has been calculated in order to determine whether the answers of these academics confirm threedimensional model in the organizational commitment scale. Path diagram established following the calculation is seen in Figure-1. 


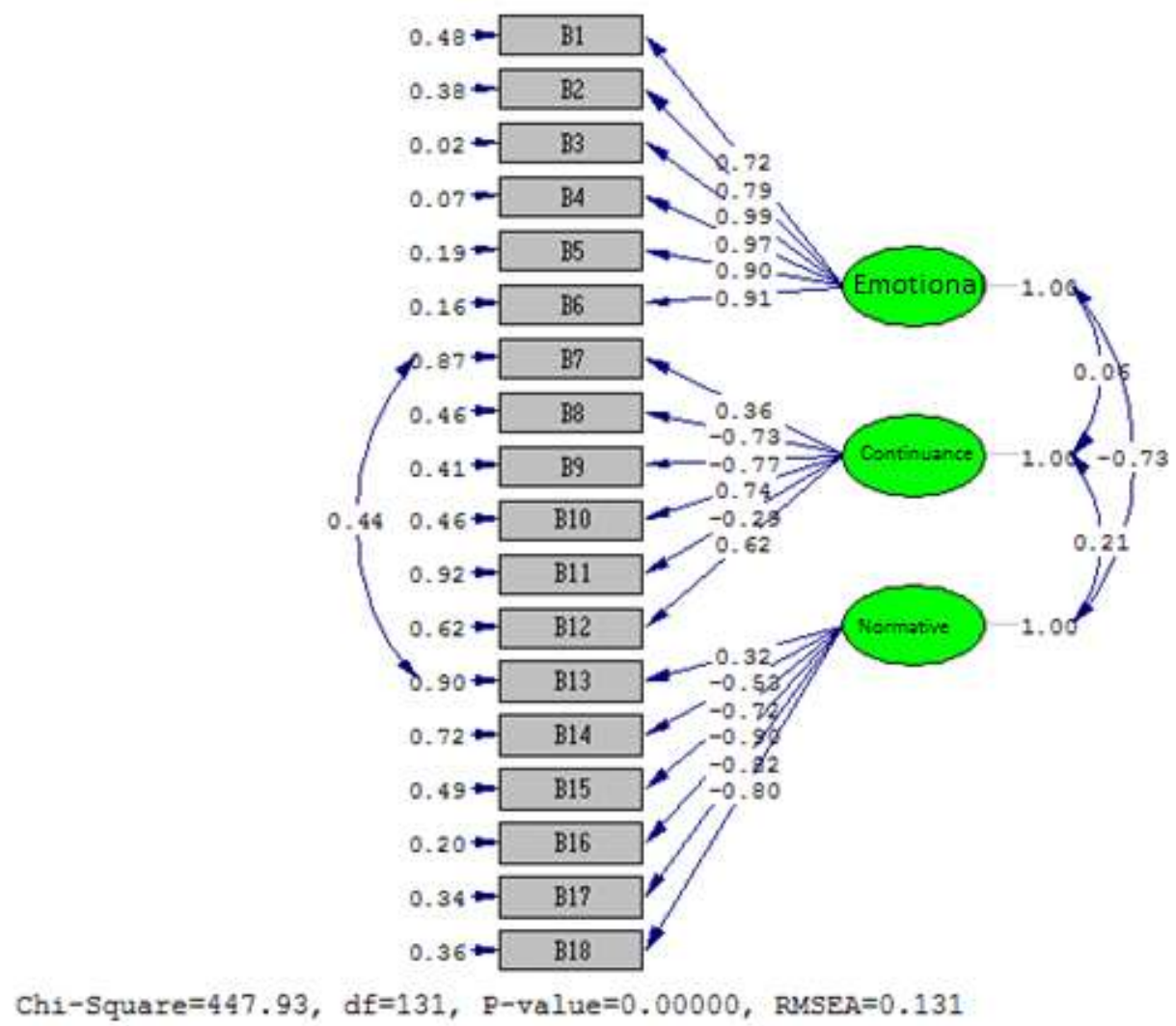

Figure-1: Path diagram established for the organizational commitment scale

As seen in the standardized coefficients in Figure-1, it is confirmed that all the items have significant explanations in all dimensions; in other words, the items have significant t-scores. When the calculated conformity indexes are examined, it is determined that $\mathrm{X}^{2} / \mathrm{sd}=3,42$; RMSEA $=0,131$; $\mathrm{CFI}=0,90 ; \mathrm{IFI}=0,90 ; \mathrm{NFI}=0,90 ; \mathrm{NNFI}=0,89$ and the model is generally confirmed.

Cronbach's alpha coefficient has been calculated to determine the reliability of answers given by participants to organizational commitment scale. Accordingly, it is calculated as 0,925 for emotional commitment, 0,678 for continuance commitment and 0,714 for normative commitment. It is confirmed that the academics whose opinions have been received within the scope of this research give valid and reliable answers to organizational commitment scale items.

\section{Turnover intention scale}

In order to determine the turnover intentions of academics whose opinions have been received within the scope of this research, "Turnover Intention Scale" developed by Rosin and Korabick (1995) and adapted to Turkish by Tanriöver (2005) has been used. Four items in the scale have been graded as five-point likert scale. High scores gotten from this scale show turnover intentions of these individuals are high, and low scores show their turnover intentions are low. During the process of adaptation, Tanriöver (2005) has calculated Cronbach's alpha coefficient for the items of turnover intention scale as 0,930 .

In this research, validity and reliability study has been carried out in accordance with the answers given by academics to the items of turnover intention scale. Firstly, confirmatory factor analysis related to four-item and one-dimensional scale model of the academics' answers has been evaluated. The established path diagram is seen in Figure-2. 


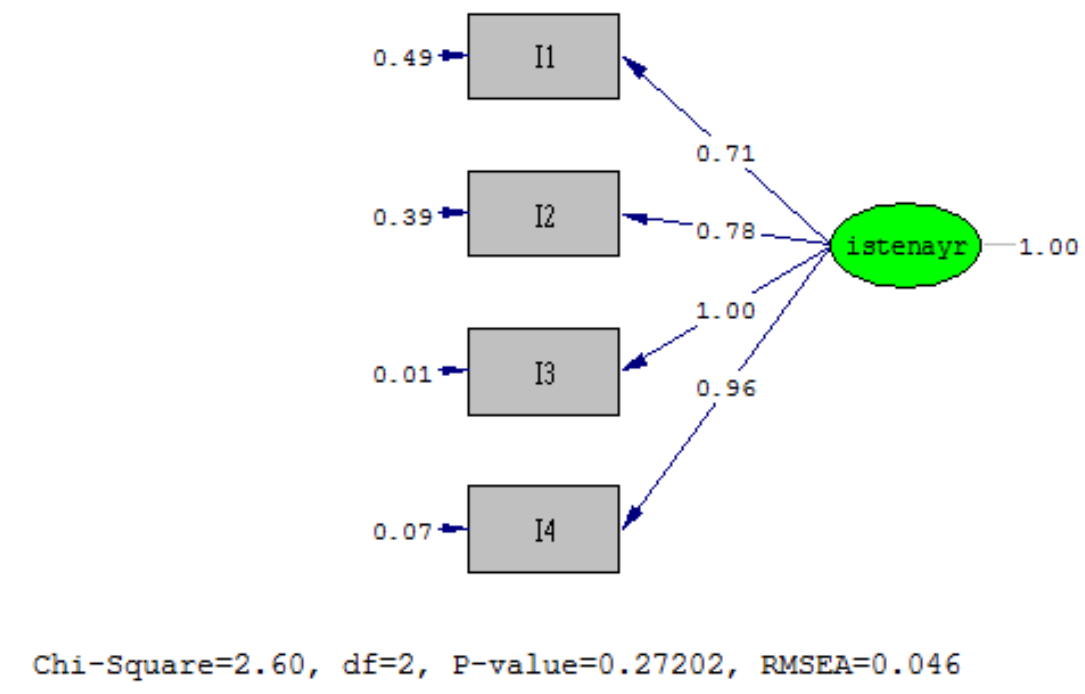

Figure-2: Path diagram established for turnover intention scale

In accordance with the answers given by academics attending to this research to the items of turnover intention scale, it is determined that the items are collected in one dimension and all the items have significant explanation coefficients. When the calculated conformity indexes are examined, it is confirmed that $\mathrm{X}^{2} / \mathrm{sd}=1,30$; RMSEA $=0,046$; CFI $=0,99$; IFI $=0,99$; NFI $=0,99$; $\mathrm{NNFI}=0,99$ and model-data conformity is provided excellently.

In order to determine the reliability of answers given by academics working at state universities to the items of scale, Cronbach's alpha coefficient is calculated as 0,853 .

It is also seen that physical education and sports academics whose opinions have been received within the scope of this research give valid and reliable answers to the items of turnover intention scale.

\section{Data analysis}

With relation to the organizational commitment and turnover intention levels of the academics, descriptive statistics have firstly been calculated. And then, t-test in unrelated measurement towards organizational commitment and turnover intention has been evaluated according to the academics' gender, marital status and availability of administrative role. On the basis of comparing organizational commitment levels according to the academics' terms of employment, one-way analysis of variance (ANOVA) has been calculated. Because variances are not homogeneous, Kruskal Wallis test has been evaluated by looking at the differences between their turnover intentions according to their terms of employment.

To determine the relationships between organizational commitment levels and turnover intentions of the academics, Pearson correlation coefficient has been evaluated. $\mathrm{p}$ significance level in difference tests are taken as 0,05 .

\section{Findings}

Table-2 Calculated descriptive statistics related to the organizational commitment and turnover intentions of the academics

\begin{tabular}{lccrrrr}
\hline Scale & $\begin{array}{c}\text { Number } \\
\text { of items }\end{array}$ & $\mathbf{N}$ & Lowest & Highest & $\overline{\mathbf{X}}$ & SS \\
\hline Emotional commitment & 6 & 143 & 6,00 & 30,00 & 23,49 & 5,73 \\
\hline Continuance commitment & 6 & 143 & 6,00 & 26,00 & 13,77 & 4,89 \\
\hline
\end{tabular}


Parasız, Ö., Koç, M., Ilgar, E., \& Şahin, M. Y., (2017). Relationship between organizational commitment and turnover intentions of academics. Journal of Human Sciences, 14(4), 4065-4076. doi:10.14687/jhs.v14i4.5076

\begin{tabular}{lrrrrrr}
\hline Normative commitment & 6 & 143 & 6,00 & 29,00 & 19,66 & 5,03 \\
\hline Turnover intention & 4 & 143 & 4,00 & 20,00 & 7,85 & 4,13 \\
\hline
\end{tabular}

In accordance with the information in Table-2, it is stated that emotional commitments of the academics are at a level of $\% 78(\overline{\mathrm{X}}=23,49)$, their continuance commitments are at a level of $\% 46(\bar{X}=13,77)$ and their normative commitments are \%66 $(\bar{X}=19,66)$. It is also identified that turnover intention scores of the participants show difference between 4,00 and 20,00 and the average is calculated as $\bar{X}=7,85$; that is to say, their turnover intentions are at a level of \%39

Table-3 T-test results in unrelated measurements related to the academics' organizational commitments and turnover intentions according to their genders

\begin{tabular}{llrrrrr}
\hline Scale & Gender & $\mathbf{N}$ & $\overline{\mathbf{X}}$ & $\mathbf{S S}$ & $\mathbf{t}$ & $\mathbf{p}$ \\
\hline Emotional commitment & Female & 33 & 22,82 & 5,67 & & \\
& Male & 110 & 23,69 & 5,76 & 0,766 & 0,445 \\
\hline Continuance commitment & Female & 33 & 13,36 & 5,28 & & \\
& Male & 110 & 13,89 & 4,78 & 0,542 & 0,589 \\
\hline Normative commitment & Female & 33 & 19,45 & 4,64 & & \\
& Male & 110 & 19,73 & 5,16 & 0,272 & 0,786 \\
\hline Turnover intention & Female & 33 & 8,39 & 4,79 & & \\
& Male & 110 & 7,68 & 3,93 & 0,867 & 0,387 \\
\hline
\end{tabular}

When we look at Table-3, it is seen that physical education and sports academics' emotional commitment $\left(\mathrm{t}_{(141)}=0,766 ; \mathrm{p}>0,05\right)$, continuance commitment $\left(\mathrm{t}_{(141)}=0,542 ; \mathrm{p}>0,05\right)$, normative commitment $\left(\mathrm{t}_{(141)}=0,272 ; \mathrm{p}>0,05\right)$ and their turnover intentions $\left(\mathrm{t}_{(141)}=0,867 ; \mathrm{p}>0,05\right)$ do not show a significant difference according to their genders. That is to say, organizational commitment and turnover intentions of female and male academics show similarity.

Table-4 T-test results in unrelated measurements related to the academics' organizational commitments and turnover intentions according to their marital status

\begin{tabular}{llrrrrr}
\hline Scale & Marital Status & $\mathbf{N}$ & $\overline{\mathbf{X}}$ & $\mathbf{S S}$ & $\mathbf{~}$ & $\mathbf{p}$ \\
\hline Emotional commitment & Married & 106 & 23,64 & 6,01 & & \\
\cline { 2 - 6 } & Single & 37 & 23,05 & 4,89 & 0,535 & 0,593 \\
\hline \multirow{2}{*}{ Continuance commitment } & Married & 106 & 13,49 & 4,98 & & \\
\cline { 2 - 6 } & Single & 37 & 14,57 & 4,59 & 1,155 & 0,250 \\
\hline \multirow{2}{*}{ Normative commitment } & Married & 106 & 19,36 & 4,84 & & \\
\cline { 2 - 6 } & Single & 37 & 20,54 & 5,51 & 1,234 & 0,219 \\
\hline Turnover intention & Married & 106 & 7,70 & 3,87 & & \\
\cline { 2 - 5 } & Single & 37 & 8,27 & 4,85 & 0,724 & 0,470 \\
\hline
\end{tabular}

When the data in Table- 3 are examined, it is seen that emotional commitment of the academics attending to this research $\left(t_{(141)}=0,535 ; \mathrm{p}>0,05\right)$, continuance commitment $\left(\mathrm{t}_{(141)}=1,155\right.$; $\mathrm{p}>0,05)$, normative commitment $\left(\mathrm{t}_{(141)}=1,234 ; \mathrm{p}>0,05\right)$ and their turnover intentions $\left(\mathrm{t}_{(141)}=0,724\right.$; $\mathrm{p}>0,05)$ do not show a significant difference according to their marital status.

It is aimed to determine whether the organizational commitment and turnover intentions of physical education and sports academics show any significant difference according to their terms of 
Parasız, Ö., Koç, M., Ilgar, E., \& Şahin, M. Y., (2017). Relationship between organizational commitment and turnover intentions of academics. Journal of Human Sciences, 14(4), 4065-4076. doi:10.14687/jhs.v14i4.5076

employment. In this direction, firstly homogeneity of variances has been tested by Levene. As a result of Levene test, it is observed that variances are homogeneous for organizational commitment level and they are not homogeneous for turnover intention.

Accordingly, to determine whether academics' organizational commitment levels show any significant difference according to their terms of employment, one-way analysis of variance has been evaluated and the results are seen in Table- 5 .

Table-5 Results of one-way analysis of variance (One-Way ANOVA) related to the academics' organizational commitment levels according to their terms of employment

\begin{tabular}{|c|c|c|c|c|c|c|}
\hline Scale & $\begin{array}{l}\text { Source } \\
\text { of variance }\end{array}$ & $\begin{array}{c}\text { Sum } \\
\text { of squares }\end{array}$ & sd & $\begin{array}{l}\text { Average } \\
\text { of squares }\end{array}$ & $\mathbf{F}$ & $\mathrm{p}$ \\
\hline \multirow[t]{3}{*}{ Emotional commitment } & Inter-group & 238,521 & 3 & 79,507 & \multirow{3}{*}{2,495} & \multirow{3}{*}{,062 } \\
\hline & In-group & 4429,213 & 139 & 31,865 & & \\
\hline & Total & 4667,734 & 142 & & & \\
\hline \multirow{3}{*}{$\begin{array}{l}\text { Continuance } \\
\text { commitment }\end{array}$} & Inter-group & 38,151 & 3 & 12,717 & \multirow{3}{*}{, 527} & \multirow{3}{*}{,665 } \\
\hline & In-group & 3335,234 & 139 & 24,138 & & \\
\hline & Total & 3393,385 & 142 & & & \\
\hline \multirow[t]{3}{*}{ Normative commitment } & Inter-group & 107,815 & 3 & 35,938 & \multirow{3}{*}{1,435} & \multirow{3}{*}{,235 } \\
\hline & In-group & 3480,073 & 139 & \multirow{2}{*}{25,036} & & \\
\hline & Total & 3587,888 & 142 & & & \\
\hline
\end{tabular}

When we look at Table-5, it is seen that score averages taken from the organizational commitment scale are similar according to the academics' terms of employment and it does not create any significant difference.

So as to determine whether academics' turnover intentions show any significant difference according to their terms of employment, Kruskal Wallis test has been evaluated and the results are seen in Table-6.

Table-6 Kruskal Wallis test results related to the academics' turnover intentions according to their terms of employment

\begin{tabular}{llllllll}
\hline Scale & $\begin{array}{l}\text { Term } \\
\text { employment }\end{array}$ & of & N & Mean rank & sd & $X^{2}$ & p
\end{tabular}

\begin{tabular}{lllllll}
\hline Turnover & $1-2$ years & 23 & 80,61 & & 1,690 & 0,639 \\
\cline { 2 - 4 } intention & $3-8$ years & 23 & 71,11 & & & \\
\cline { 2 - 4 } & $9-14$ years & 37 & 66,61 \\
\cline { 2 - 4 } & 15 years and above & 46 & 72,75 & \\
\hline
\end{tabular}

In accordance with the data in Table- 6 , it is stated that academics' turnover intentions do not show any significant difference according to their terms of employment $\left(X_{(3)}^{2}=1,690 ; p>0,05\right)$. In other words, it is confirmed that academics' turnover intentions are similar even if their terms of employment are different.

Table-7 T-test results in unrelated measurements related to the academics' organizational commitment and turnover intentions according to availability of administrative role 
Parasız, Ö., Koç, M., Ilgar, E., \& Şahin, M. Y., (2017). Relationship between organizational commitment and turnover intentions of academics. Journal of Human Sciences, 14(4), 4065-4076. doi:10.14687/jhs.v14i4.5076

\begin{tabular}{lllllll}
\hline Scale & Administrative role & $\mathbf{N}$ & $\overline{\mathbf{X}}$ & $\mathbf{S S}$ & $\mathbf{t}$ & $\mathbf{p}$ \\
\hline $\begin{array}{l}\text { Emotional } \\
\text { commitment }\end{array}$ & Yes & 46 & 23,48 & 6,90 & & \\
\cline { 2 - 5 } $\begin{array}{l}\text { Continuance } \\
\text { commitment }\end{array}$ & No & 97 & 23,49 & 5,13 & 0,016 & 0,987 \\
\hline $\begin{array}{l}\text { Normative } \\
\text { commitment }\end{array}$ & No & 46 & 12,30 & 3,91 & & \\
\hline Turnover intention & Yes & 97 & 14,46 & 5,16 & 2,513 & 0,013 \\
\cline { 2 - 6 } & No & 46 & 18,87 & 5,23 & & \\
& Yes & 97 & 20,04 & 4,91 & 1,305 & 0,194 \\
\hline
\end{tabular}

In accordance with the data in Table- 7 , it is determined that academics' emotional commitment $\left(\mathrm{t}_{(141)}=0,016 ; \mathrm{p}>0,05\right)$, normative commitment $\left(\mathrm{t}_{(141)}=1,305 ; \mathrm{p}>0,05\right)$ and turnover intentions $\left(\mathrm{t}_{(141)}=0,565 ; \mathrm{p}>0,05\right)$ do not show any significant difference according to the availability of administrative role. In addition to this, it is stated that academics' continuance commitments show a significant difference $\left(\mathrm{t}_{(141)}=2,513 ; \mathrm{p}<0,05\right)$ according to their administrative roles. When the average scores are examined, academics who have an administrative role $\bar{X}=14,46 \pm 5,16)$ have higher compulsory attendance when compared with the academics who do not have any administrative roles $(\bar{X}=12,30 \pm 3,91)$.

- Relationship statistics

Pearson correlation coefficient has been calculated with the purpose of determining the relationships between organizational commitment and turnover intentions of the academics whose opinions have been received within the scope of this research.

Table- 8 Relationships between organizational commitment and turnover intentions of the academics

\begin{tabular}{|c|c|c|c|c|c|}
\hline Variable/Values & & $\begin{array}{l}\text { Emotional } \\
\text { commitment }\end{array}$ & $\begin{array}{l}\text { Continuance } \\
\text { commitment }\end{array}$ & $\begin{array}{l}\text { Normative } \\
\text { commitment }\end{array}$ & $\begin{array}{l}\text { Turnover } \\
\text { intention }\end{array}$ \\
\hline \multirow{3}{*}{$\begin{array}{l}\text { Emotional } \\
\text { commitment }\end{array}$} & $\mathrm{R}$ & 1 &,- 028 &, $583^{* *}$ &,$- 625^{* *}$ \\
\hline & $\mathrm{P}$ & & ,737 & ,000 &, 000 \\
\hline & $\overline{\mathrm{N}}$ & & 143 & 143 & 143 \\
\hline \multirow{3}{*}{$\begin{array}{l}\text { Continuance } \\
\text { commitment }\end{array}$} & $\mathrm{R}$ & & 1 & $248^{* *}$ & , 140 \\
\hline & $\mathrm{P}$ & & & ,003 &, 095 \\
\hline & $\overline{\mathrm{N}}$ & & & 143 & 143 \\
\hline \multirow{3}{*}{$\begin{array}{l}\text { Normative } \\
\text { commitment }\end{array}$} & $\mathrm{R}$ & & & 1 &,$- 393^{* *}$ \\
\hline & $\mathrm{P}$ & & & & ,000 \\
\hline & $\mathrm{N}$ & & & & 143 \\
\hline \multirow{3}{*}{$\begin{array}{l}\text { Turnover } \\
\text { intention }\end{array}$} & $\mathrm{R}$ & & & & 1 \\
\hline & $\mathrm{P}$ & & & & \\
\hline & $\bar{N}$ & & & & \\
\hline
\end{tabular}

When Table- 8 is examined, it is seen that there is a negative and medium-level significant relationship between emotional commitment levels and turnover intentions of the academics $(\mathrm{r}=$ - 
Parasız, Ö., Koç, M., Ilgar, E., \& Şahin, M. Y., (2017). Relationship between organizational commitment and turnover intentions of academics. Journal of Human Sciences, 14(4), 4065-4076. doi:10.14687/jhs.v14i4.5076

$0,625 ; \mathrm{p}<0,05)$. In other words, it is stated that turnover intentions of the academics show decrease as their emotional commitments towards their organizations show increase. It is also identified that there is not any significant relationship between organizational commitments and turnover intentions of the academics $(r=0,140 ; p>0,05)$; on the other hand, there is a negative and low-level significant relationship between their normative commitment levels and turnover intention levels $(\mathrm{r}=-0,393 ; \mathrm{p}<0,05)$. That is to say, turnover intentions of the academics show decrease as their normative commitments show increase.

It is observed that there is a positive and medium-level significant relationship between emotional commitments and normative commitments of the academics $(r=0,583 ; p<0,05)$. Normative commitments of the academics are in the tendency to show increase as their emotional commitment increase. It is also determined that there is a positive and low-level relationship between their normative and continuance commitments $(r=0,248 ; p<0,05)$. Besides, there is not any significant relationship between normative and continuance commitments of the academics $(\mathrm{r}=-0,028 ; \mathrm{p}>0,05)$.

\section{Discussion}

In the light of these data, it is stated that academics' average scores related to the "Emotional Commitment" sub-dimension are at a level of \%78 $(\overline{\mathrm{X}}=23,49)$ and their normative commitments are at a high level with \%66 $(\overline{\mathrm{X}}=19,66)$; the scores of continuance commitments with $\% 46(\overline{\mathrm{X}}=13,77)$ and turnover intention with $\% 39(\overline{\mathrm{X}}=7,85)$ are at a low level (Table-2).

In this research, that the academics' emotional commitments are high can be expressed that they see their works not only as a job but also as a life style. Besides, low scores of turnover intentions can be derived from that they want to stay in the same university at the rest of their careers and they see themselves as a part of the university.

When the related literature is investigated, it is seen in the study of Ermiş (2014) that average scores $(\bar{X}=3,9)$ related to the sub-dimension "Emotional Commitment" of the academics working in the school of physical education and sports take place in the first rank and "Continuance Commitment" are at a low level with $(\bar{X}=2,3)$. Aydemir and Ersan (2011) identify emotional commitment of the academic and administrative staff working in the new-established universities as $(\bar{X}=3,5)$, their normative commitment as $(\bar{X}=3,2)$ and their continuance commitment as $(\bar{X}=2,9)$. In a study carried out by Boylu et al. at Gazi University, emotional commitments of academics take place in the first rank with a rate $(\bar{X}=3,65)$ while their continuance commitments take place in the last rank with a rate $(\bar{X}=2,63)$.

In this context, it can be said that among organizational commitments, academics' senses which are mostly related to the emotional commitment are high and this finding obtained from the research is in concordance with the literature.

Results show any difference between organizational commitment and turnover intentions of the academics attending to the research has been found according to the variables like their genders, marital status and terms of employment.

Related to the factors affecting organizational commitment Oliver (1990) states that the effects of demographic factors on organizational commitment are relatively less, and organizational prizes and business assets have stronger relationship with organizational commitment.

This finding shows parallelism with the results of the studies done on academics (Ermiş, 2014; Boylu et al., 2007) and employees working at different jobs (Ellemers et al., 2004; Kennedy and Anderson, 2005; İnce and Gül, 2005; Belli and Ekici 2012; Seyhan, 2014).

It is determined that academics included in the research do not show any difference on the basis of their emotional commitment $\left(t_{(141)}=0,016 ; p>0,05\right)$, normative commitment $\left(t_{(141)}=1,305\right.$; 
Parasız, Ö., Koç, M., Ilgar, E., \& Şahin, M. Y., (2017). Relationship between organizational commitment and turnover intentions of academics. Journal of Human Sciences, 14(4), 4065-4076. doi:10.14687/jhs.v14i4.5076

$\mathrm{p}>0,05)$ and turnover intentions $\left(\mathrm{t}_{(141)}=0,565 ; \mathrm{p}>0,05\right)$ according to the availability of administrative role. In addition to this, can be said that academics' continuance commitments show a significant difference according to administrative role $\left(t_{(141)}=2,513 ; \mathrm{p}<0,05\right)$. Academics who do not have any administrative roles have higher level of compulsory attendance (Table-7).

According to the correlation between turnover intention and organizational commitment constituents of the research group, it is stated that there is a medium-level and negative $(r=-0,625$; $\mathrm{p}<0,05)$ relationship between emotional commitment levels and turnover intentions and a low-level and negative $(\mathrm{r}=-0,393 ; \mathrm{p}<0,05)$ relationship between normative commitment levels and turnover intentions (Table-8). In other words, turnover intentions of the academics show decrease as their emotional and normative commitments show increase.

According to the conducted researches, organizational commitment has a positive relationship with job satisfaction and productivity, and it decreases lack of continuity and leaving (Lingard and Lin, 2004: 410; Sökmen and Şimşek, 2016; Uştu and Tümkaya, 2017). Meyer and Allen (1997) emphasize that employees whose organizational commitments are high are seen as the employees that are more precious for organizations and that should be kept in the organization. On the other hand, according to Balay (2000), depending on the organizational commitment behavioral results have strong relationships with commitment. Among them, especially job satisfaction, motivation, attendance and wish of staying in the organization have positive relationship with organizational commitment while they have negative relationship with job switches and turnover intention.

When the related literature is examined, some studies supporting the research results are seen. For instance, according to Özdemir and Yaylı (2014), there is an opposite (negative) and high relationship $(\mathrm{r}=,-709)$ between emotional commitment dimension and turnover intention dimension and an opposite (negative) and low relationship $(\mathrm{r}=,-436)$ with normative commitment dimension. Chang et al. (2007) have found that normative commitment has a negative effect on organizational turnover intention and emotional commitment has a negative effect on vocational turnover intention. In a study of Das et al. (2013), they inferred that there is a negative relationship between organizational commitment and turnover intention.

As a result, it can be concluded that the academics' see their works not only as a job but also as a life style, among organizational commitments, academics' senses which are mostly related to the emotional commitment and there is no difference between organizational commitment and turnover intentions of the academics attending to the variables like their genders, marital status and terms of employment.

\section{REFERENCES}

Allen, N. J., Meyer, J. P. (1991). A Three-Component Conceptualization of Organizational Commitment. Human Resource Management Review, 1, 61-89.

Aydemir M., Erşan C. (2011). Yeni Kurulan Üniversitelerde Örgütsel Bağlllık Sorunu. Afyon Kocatepe Üniversitesi, İ.I.B.F. Dergisi, XIII(I), 55-72.

Bağcı, Z., Bursalı, Y. M. (2011). Yöneticilerin Güç Kaynaklarının Çalışanlanın Örgüte Bağlllıklanı Üzerine Etkisi: Çalışanların Algılamalarına Bağımlı Analitik Bir İnceleme. Pamukkale Üniversitesi, Sosyal Bilimler Enstitüsü Dergisi, 9, 9-21.

Balay, R. (2000). Yönetici ve Öğretmenlerde Örgütsel Bağllık. Ankara: Nobel Yayın Dağıtım.

Bartlett, K. R. (1999). The Relationship Between Training and Organizational Commitment In The Health Care Field. (The Degree of Doctor). The University of Illinois, Urbana.

Belli, E., Ekici, S. (2012). Ege Bölgesindeki Gençlik ve Spor İl Müdürlüklerinde Çalışan Personelin Örgütsel Bağlllkklarının Araştırılması. Selçuk Üniversitesi Beden Eğitimi ve Spor Bilim Dergisi, 14 (2), 171-178.

Boylu, Y., Pelit, E., Güçer, E. (2007). Akademisyenlerin Örgütsel Bağlllk Düzeyleri Üzerine Bir Araştırma. Finans Politik \& Ekonomik Yorumlar, 44(511), 55-74. 
Parasız, Ö., Koç, M., Ilgar, E., \& Şahin, M. Y., (2017). Relationship between organizational commitment and turnover intentions of academics. Journal of Human Sciences, 14(4), 4065-4076. doi:10.14687/jhs.v14i4.5076

Chang, H. T., Chi, N. W., Miao, M. C. (2007). Testing The Relationship Between Three-Component Organizational/Occupational Commitment and Organizational/ Occupational Turnover Intention using A Non-Recursive Model. Journal Of Vocational Behavior, 70, 352-368.

Çetin, M. Ö. (2004). Örgüt Kültürü ve Örgütsel Bağllılk. Ankara: Nobel Yayın Dağ1tım.

Das, D., Nandialath, A., Mohan, R. (2013). Feeling Unsure: Quit Or Stay? Uncovering Heterogeneity in Employees Intention To Leave in Indian Call Centers. The International Journal Of Human Resource Management, 24(1), 15-34.

Ellemers, N., Van Den Heuvel, H., Gilder, D., Maass, A., Bonvin1, (2004). A. The Underrepresentation of Women in Science: Differential Commitment or The Queen Bee Syndrome. British Journal of Social Psychology, 43, 315-338.

Ermiş S. A. (2014). Akademisyenlerin Örgütsel Bağlllık ve İş Tatmini Düzeyleri ve İlişkisi. (Yüksek Lisans Tezi). Gazi Üniversitesi/Sağllk Bilimleri Enstitüsü, Ankara.

Güner, A. R. (2007). Sağllk Hizmetlerinde Örgütsel Bağlllkk, İşe Bağlllk ve İşTatmini Arasındaki İlişkilerin Modellenmesi. (Yüksek Lisans Tezi). Akdeniz Üniversitesi/Sosyal Bilimler Enstitüsü, Antalya.

İnce, M., Gül, H. (2005). Yönetimde Yeni Bir Paradigma Örgütsel Bağllılk. Ankara: Çizgi Kitabevi.

Kennedy, J.R., Anderson, R.D. (2005). Subordinate-Manager Ender Combination And Perceived Leadership Style Influence on Motions, Self- Esteem and Organizational Commitment. Journal of Business Research, 58, 115-125.

Lingard, H., Lin, J. (2004). Career, Family and Work Environment Determinants Of Organisational Commitment Among Women in The Australian Construction Industry. Construction Management and Economics, 22(4), 409-420.

Meyer, J. P., Allen, N. J. (1997). Commitment in the Workplace, Theory, Research and Application. London: Sage Publications Inc.

Oliver, N. (1990). Work Rewars, Work Values and Organizational Commitment in Employee-owned Firm. Evidence From the U.K. Human Relations, 43(6), 513-526.

Özdemir H., Yaylı A. (2014). The Relationship Among Employees Loyalty, Performance and Turnover Intention. JRTR, 1 (1), 48-58.

Porter, L.W., Steers, R.M. (1974). Organizational Commitment, Job Satisfaction And Turnover Among Psychiatric Technicians. Journal of Applied Psychology, 59(October), 603-60.

Rosin, H., Korabik, K. (1995). Organisational experiences and propensity to leave-a multivariate investigation of men and women managers, Journal of Vocational Behaviour, 46(1), 1-16.

Seyhan, M. (2014). İşletmelerde Örgütsel Bağlllk ve Örgütsel Bağlllğı Etkileyen Faktörler: Gümrük Memurları Üzerine Bir Araşturma. (Yüksek Lisans Tezi). Trakya Üniversitesi /Sosyal Bilimler Enstitüsü, Edirne.

Solmaz, H. (2010). Örgütsel Özdeşleşmenin İșten Ayrilma Niyetine Etkisinde Örgütsel Adaletin Aracilık Rolü. (Yüksek Lisans Tezi). Ufuk Üniversitesi/Sosyal Bilimler Enstitüsü, Ankara.

Somuncu, F. (2008). Örgütsel Bağllık ve Örgütsel Bağlllığ1 Geliştirme Araçları: Özel Bir Hizmet İşletmesinde Araştırma. (Yüksek Lisans Tezi) Anadolu Üniversitesi /Sosyal Bilimler Enstitüsü, Eskişehir.

Sökmen, A. Şimşek, T. Örgütsel Bağlllık, Örgütle Özdeşleşme, Stres ve İşten Ayrılma Niyeti İlişkisi: Bir Kamu Kurumunda Araşurma. İktisadi ve İdari Bilimler Fakültesi Dergisi, 2016; 18(3): 606-620.

Swailes, S. (2002). Organizational Commitment: A Critique Of The Construct And Measures, International Journal of Management Reviens, 4(2), 155-178.

Tanröver, U. (2005). The Effects of Learning Organization Climate and Self Directed Learning on Job Satisfaction, Affective Commitment and Intention to Turnover (Yüksek Lisans Tezi). Marmara Üniversitesi, İstanbul.

Tolukan, E., Bayrak, M., \& Doğan, P. K. (2017) Antrenörlerin Sosyal Kaytarma Algılarının İncelenmesi. Gaziantep Üniversitesi Spor bilimleri dergisi., 2(1), 1-13.

Uştu H., Tümkaya S. Predictors of Primary School Teachers' Organizational Commitment and Detecting Teachers' Organizational Commitment, Occupational Commitment and Intent to Leave Levels, Elementary Education Online, 2017; 16(3): 1262-1274

Vanderberg, R. J., Scarpella, V. (1994). A Longitudinal Assessment Of The Determinant Relationship Between Employee Commitments To The Occupation And The Organization. Journal Of Organizational Behavior, 15, 535.

Varol, F. (2010). Örgütsel Bağllıtk ve İş̧ Tatmininin İșten Ayrllma Niyetine Olan Etkisi: Konya İli İlaç Sektörü Çalş̧anları Üzerine Bir Uygulama.Selçuk Üniversitesi, Konya. 